\title{
Slant shear strength of hybrid concrete made with old and new parts using reactive and inert waste powders
}

\author{
James H. Haidoํㅜㄴ Youkhanna Zayia Dinkha², Badorul H. Abu-Bakar ${ }^{3}$ \\ ${ }^{1}$ College of Engineering, University of Duhok, Duhok, Kurdistan Region - Iraq \\ ${ }^{2}$ College of Engineering, University of Duhok, Duhok, Kurdistan Region - Iraq \\ ${ }^{3}$ School of Civil Engineering, Universiti Sains Malaysia, Pinang, Malaysia
}

\begin{abstract}
Manufactured reactive powders, as a silica fume, are usually used in production of high strength concrete with for retrofitting purposes of concrete structures. The efficiency of inert waste glass powder in hybrid concrete fabrication has not been widely investigated, thus further studies are essentially considered in this area. In the present study,

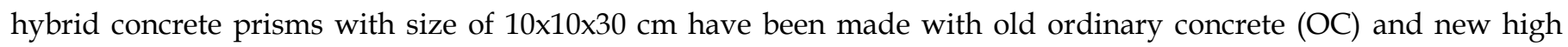
strength concrete (HSC). High strength of new concrete part of these prisms is achieved via using of waste glass powder, silica fume and mixture of them. The roughness of interfacial surface between old and new parts of hybrid concrete is improved in various manners with utilizing sand blast, holes and grooves. Performance of these elements has been measured in terms of slant shear strength and mode of failure. The results have been shown that there is a relatively similar strength with using retrofitted concrete made with the used powder which includes silica fume, glass powders, and their mixture, the mixture of both powders, namely, silica fume and waste glass powders is regarded a best choice in the present stud. It is demonstrated also that the grooved interface between old and new concretes induces proper strength equivalent to $89 \%$ of control concrete prisms strength.
\end{abstract}

KEYWORDS : waste glass powder; hybrid concrete prism; interfacial surface between concretes; green concrete.

\section{INTRODUCTION}

In any concrete structure that has been built or under construction, the engineers may face main problem in engineering history which is deterioration of reinforced concrete material (Tayeh et el.,2012). Since the time they found out this problem, they have been searching for solutions to ensure the effective structural management. So, the suitable solution for this problem is represented by good bond repairing or retrofitting by a material with high compressive strength and reasonable durability. During few years ago, researches launched to find solutions for concrete deterioration with limited concentration on using of high strength concrete as retrofitted material. HSC is among the trendiest promising cementitious

Academic Journal of Nawroz University

(AJNU) Volume 7, No 4 (2018).

Regular research paper : Published 21 December 2018

Corresponding author's e-mail : james.haido@uod.ac

Copyright $@ 2017$ James H. Haido ${ }^{1}$, Youkhanna Zayia

Dinkha², B.H. Abu-Bakar³.

This is an open access article distributed under the Creative Commons Attribution License. materials that developed with potential to be a viable solution for improving the resilience and sustainability of the existed infrastructure because of its high strength, durability and energy absorption capacity compared with ordinary concrete. High performance concretes are typically made by cement (basically with dosage more than conventional concrete), super-plasticizer, silica fume, fine sands (maximum grain size of $0.8 \mathrm{~mm}$ ) (Habel et al., 2006) with steel fibers as optional component (Sarsam and Mohammed, 2014). The superior compressive and tensile strengths of this concrete can be attributed to the presence of fine compounds. It was previously demonstrated in many studies (Graybeal,2006; Pfeifer et al., 2009; Graybeal, 2009) that HSCs are highly strong against chemical attack, abrasion, freeze-thaw cycles, and chloride penetration. Common sorts of HSC are fiber reinforced concretes (FRC) (Brandt, 2008), slurry infiltrated fiber concrete (SIFCON) (Naaman and Homrich, 1989), multi-scale cement composite (MSCC) (Rossi, 1997), hybrid fiber concretes (HFC) (Markovic, 2006), high performance fiber reinforced cement composites (HPFRCC) 
(Naaman, and Reinhardt, 2006), engineered cementitious composite (ECC) (Li, 2003, Li et al., 2001), ultra high performance fiber reinforced concrete (UHPC) (Wile et al., 2011; Smarzewski and Barnat-Hunek, 2017), etc. The retrofitting of deteriorated concrete with HSC material needs repairing new concrete required to place next to old defective one (Momayez et al. 2005). Accordingly, a weak bond will be arising between old and new concretes in hybrid concrete members (Momayez; Yuan and Marosszeky, 2005). Thus, to produce a durable and effective bond in these structures, a proper repair is considered main requirement (Ali and Ambalavanan, 1999; $\mathrm{Mu}$ et al., 2002). Some endeavors (Harris et al., 2011; Santos and Julio, 2011; Vaysburd and Emmons, 2000; Azad and Hakeem, 2013; Denarié and Brühwiler 2006; Juli et al., 2004; Garbacz et al., 2005) have been started recently to investigate the behavior of hybrid concrete. Based on the aforementioned literature review, the performance of hybrid concrete made with ordinary concrete and HSC has not been studied extensively. Thus, more investigations in this direction are considered necessary. In addition, the influence of the waste glass powder on the mechanical properties of hybrid concrete has not been examined so far.

The objectives of present work are:

1- To evaluate the efficiency of waste glass powder in enhancing the mechanical properties of hybrid concrete made with old OC and retrofitted new HSC. 2- To investigate the effect of roughening mode for the interfacial surface between OC and HSC on the slant shear strength of hybrid concrete.

\section{EXPERIMENTAL PROGRAM}

\subsection{Materials}

The used materials in the hybrid concrete are similar to those for normal concrete in addition to powders (i.e. silica fume and waste glass powder) and superplasticizer. In HSC, fine materials are employed alone with utilizing water-cement ratio lesser than that for ordinary concrete. Ordinary Portland cement has been used in current study, with properties given in Table 1. River sand with specific gravity and density of 2.67 and $1828 \mathrm{~kg} / \mathrm{m}^{3}$, respectively has been utilized in present concrete mixes. This aggregate is well washed; air dried and separated according the standard set of sieves. Sieve analysis has been performed for fine aggregate using grades meeting with the standard limitations of ASTM (2007) as given in Table 2. Partially crushed gravel has been employed as coarse aggregate with a maximum size of $20 \mathrm{~mm}$. Clean and free from contamination tap water has been used in fresh concrete mixing and hard concrete curing. Two types of powder have been used, namely, gray silica fume and white waste glass powder shown in (fig. 1) to produce very high strength concrete which is employed as new part of hybrid concrete element. The properties of the used silica fume are tabulated in Table 3. The chemical composition and physical properties of the used glass powder are shown in Tables 4 and 5 respectively. Hence, there is no pozzolanic reactivity of this powder in concrete mix due to that their particles size is greater than $100 \mu \mathrm{m}$ as demonstrated by Ankur and Randheer (2012).

Table (1) : Characteristics of the used cement

\begin{tabular}{|c|c|c|c|c|c|}
\hline Property & $\begin{array}{c}\text { Initial } \\
\text { setting time }\end{array}$ & $\begin{array}{c}\text { Final } \\
\text { setting time }\end{array}$ & $\begin{array}{c}\text { Specific } \\
\text { gravity }\end{array}$ & fineness & Density \\
\hline $\begin{array}{c}\text { Test } \\
\text { Results }\end{array}$ & $151 \mathrm{~min}$. & $2.25 \mathrm{~h}$ & 3.2 & $306 \mathrm{~m}^{2} / \mathrm{kg}$ & $1400 \mathrm{~kg} / \mathrm{m}^{3}$ \\
\hline
\end{tabular}

Table (2) : Grading of the used sand

\begin{tabular}{|c|c|c|}
\hline Sieve No. & \% Passing & $\begin{array}{c}\text { passing limits } \\
\text { ASTM C33 [27] }\end{array}$ \\
\hline $9.5 \mathrm{~mm}$ & 100 & 100 \\
\hline $4.75 \mathrm{~mm}$ & 100 & $95-100$ \\
\hline $2.36 \mathrm{~mm}$ & 85 & $80-100$ \\
\hline $1.18 \mathrm{~mm}$ & 72 & $50-85$ \\
\hline $600 \mu \mathrm{m}$ & 51 & $25-60$ \\
\hline $300 \mu \mathrm{m}$ & 21 & $10-30$ \\
\hline $150 \mu \mathrm{m}$ & 3 & $2-10$ \\
\hline
\end{tabular}




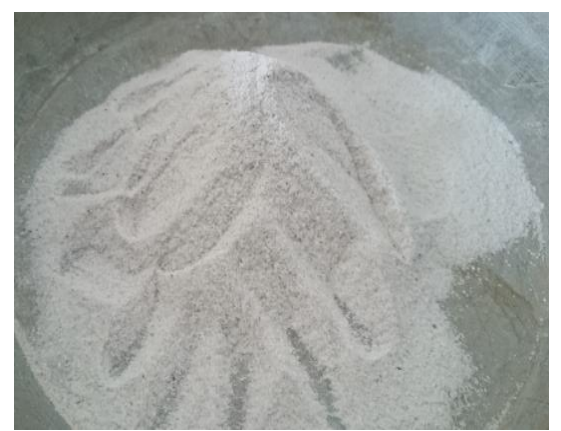

Waste Glass Powder

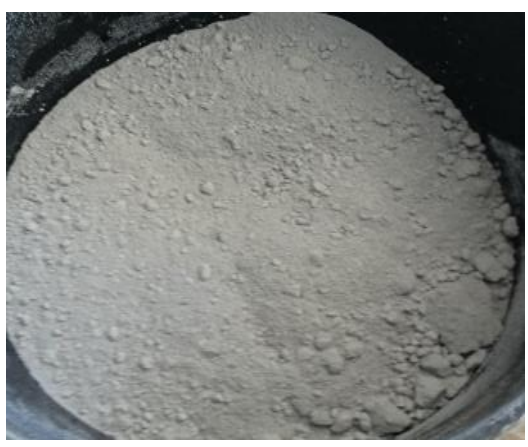

Silica Fume

Fig (1) : The Powders used in HSC

Table (3) : Physical and chemical properties of silica fume

\begin{tabular}{|c|c|}
\hline Property & Magnitude \\
\hline \% Retain on 45 micron sieve & 2 \\
\hline Bulk density $\left(\mathrm{kg} / \mathrm{m}^{3}\right)$ & 1002 \\
\hline Pozzolanic activity $(\%)$ & 128 \\
\hline$\%$ Moisture content at $105{ }^{\circ} \mathrm{C}$ & 0.06 \\
\hline$\%$ Loss on Ignition at $750^{\circ} \mathrm{C}$ & 0.38 \\
\hline \%Silicon Dioxide $\left(\mathrm{SiO}_{2}\right)$ & \\
\hline
\end{tabular}

Table (4) : Chemical composition of waste glass powder

\begin{tabular}{|c|c|}
\hline Composition & \% by mass \\
\hline $\mathrm{SiO}_{2}$ & 67.78 \\
\hline $\mathrm{CaO}$ & 24.32 \\
\hline $\mathrm{Al}_{2} \mathrm{O}_{3}$ & 3.00 \\
\hline $\mathrm{MgO}$ & 2.60 \\
\hline $\mathrm{Na}_{2} \mathrm{O}$ & 1.99 \\
\hline $\mathrm{SO}_{3}$ & 1.00 \\
\hline $\mathrm{SrO}$ & 0.76 \\
\hline $\mathrm{Fe}_{2} \mathrm{O}_{3}$ & 0.68 \\
\hline $\mathrm{K}_{2} \mathrm{O}$ & 0.36 \\
\hline $\mathrm{TiO}_{2}$ & 0.10 \\
\hline $\mathrm{P}_{2} \mathrm{O}_{5}$ & 0.11 \\
\hline $\mathrm{MnO}$ & 0.03 \\
\hline
\end{tabular}

Table (5) : Physical properties of waste glass powder

\begin{tabular}{|c|c|}
\hline Specific Gravity & 2.60 \\
\hline Density & $1.3 \mathrm{gm} / \mathrm{cm}^{3}$ \\
\hline $\begin{array}{c}\text { Fineness Passing } \mathbf{8 5 0} \\
\boldsymbol{\mu m}\end{array}$ & $95 \%$ \\
\hline
\end{tabular}

A reasonable dosage of superplasticizer (i.e. given in Table 6) has been used in present work to obtain the workable high performance concrete mixes with very low water-cement ratio $(\mathrm{w} / \mathrm{c})$.

\subsection{Mix Proportions and Mold Dimensions:}

Hybrid concrete samples have been prepared with two concrete strata, namely, ordinary concrete (substrate portion) that represent old deteriorated concrete and newly cast high strength concrete (retrofitted portion). Silica fume, waste glass powder and mixture of silica fume and glass powder is used to fabricate a new concrete part of hybrid concrete with high strength. Due to the effect of the interface 
between old and new concretes on the strength of hybrid concrete, many roughening modes have been employed. In order to achieve the required strength, mix design is performed for OC and HSC with taking into account the strength and workability. Four concrete mixes are designed according to $\mathrm{ACI}$ and selected in present study, namely, OC and HSC made with three different powders as given in Table 3. Standard cubes with size of $100 \times 100 \times 100 \mathrm{~mm}$ have been made using these mixes to measure concrete compressive strength at age of 28 days.

Table (6) : Selected concrete mixes of present OC and HSC

\begin{tabular}{|c|c|c|c|c|}
\hline Material & $\begin{array}{c}\text { Normal Concrete } \\
\left(\mathbf{k g} / \mathbf{m}^{3}\right)\end{array}$ & \multicolumn{3}{|c|}{ Mix Proportions for HSC (Kg/m $\left.\mathbf{m}^{3}\right)$} \\
\hline Cement $\odot$ & 400 & 900 & 900 & 800 \\
\hline Sand (S) & 600 & 1008 & 1008 & 800 \\
\hline Gravel (G) & 1200 & - & - & - \\
\hline Silica Fume (SF) & - & 225 & - & 120 \\
\hline Glass Powder (GP) & - & - & 225 & 160 \\
\hline Water (W) & 220 & 171 & 202.5 & 64.8 \\
\hline $\begin{array}{c}\text { Super Plasticizer } \\
\text { (SP) }\end{array}$ & - & 67.5 & 67.5 & \\
\hline
\end{tabular}

Special molds (Fig. 2) are used in fabrication of present hybrid concrete specimens with specific dimensions (Fig. 3).
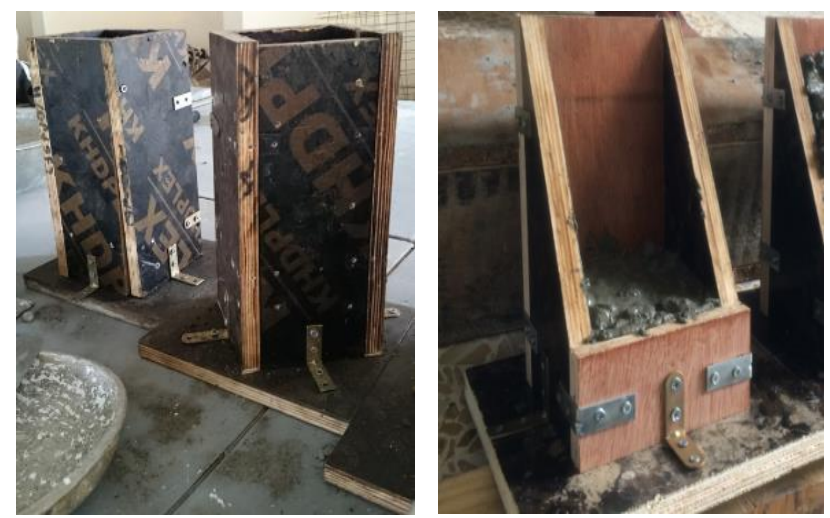

Fig (2) : Molds of hybrid concrete

\subsection{Preparation of the Hybrid Concrete Specimens.}

In old part (substrate part) preparation, dry components (cement and aggregates) are mixed for 30s followed by adding some of water with mixing for another 30 s. The mixer is stopped for 3-5 min to give the mixture a time for absorption. Thereafter, the remaining water is introduced and mixing was continued for a period of 2$2.5 \mathrm{~min}$. The concrete was cast (Fig. 4) in the molds in three layers of fresh concrete with average compaction of 35 blows per layer and some blows on the side of the mold to get rid of the interrupted air. Finally, the leveling of surface has been performed for the freshly molded concretes. The filled molds are stored in the lab

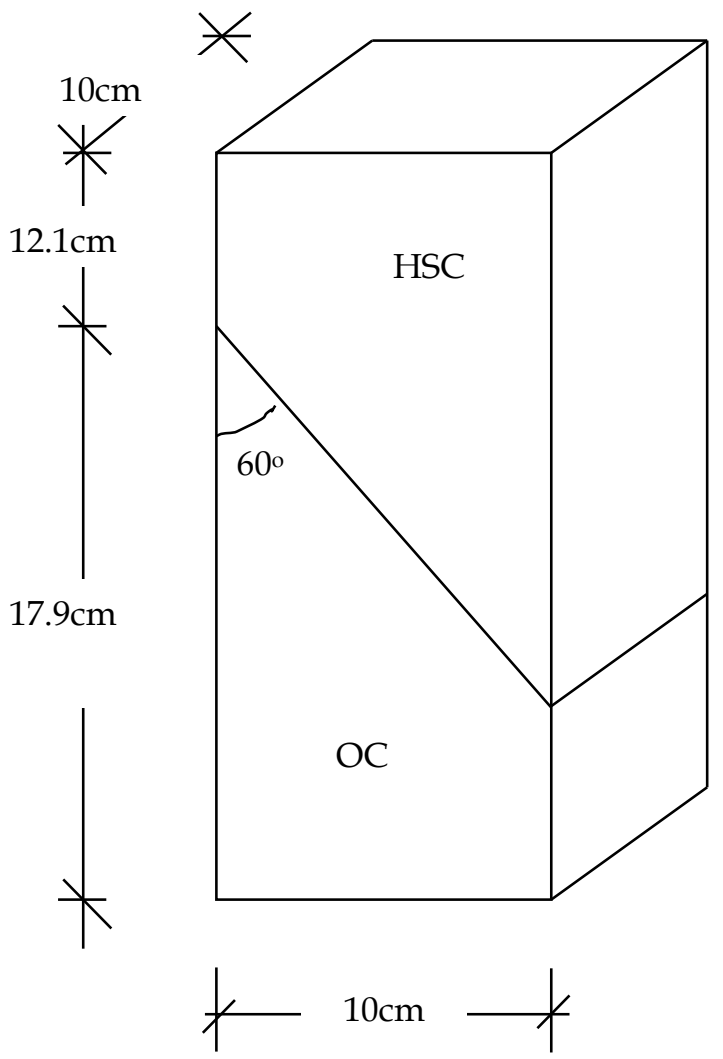

Fig (3) : Dimensions of hybrid concrete mold 
at temperature of $24^{\circ} \mathrm{C}$ for 24 hours. Thereafter, the molds are removed and hardened concrete samples (Fig. 5) are stored in the water for 28 days at the lab temperature.

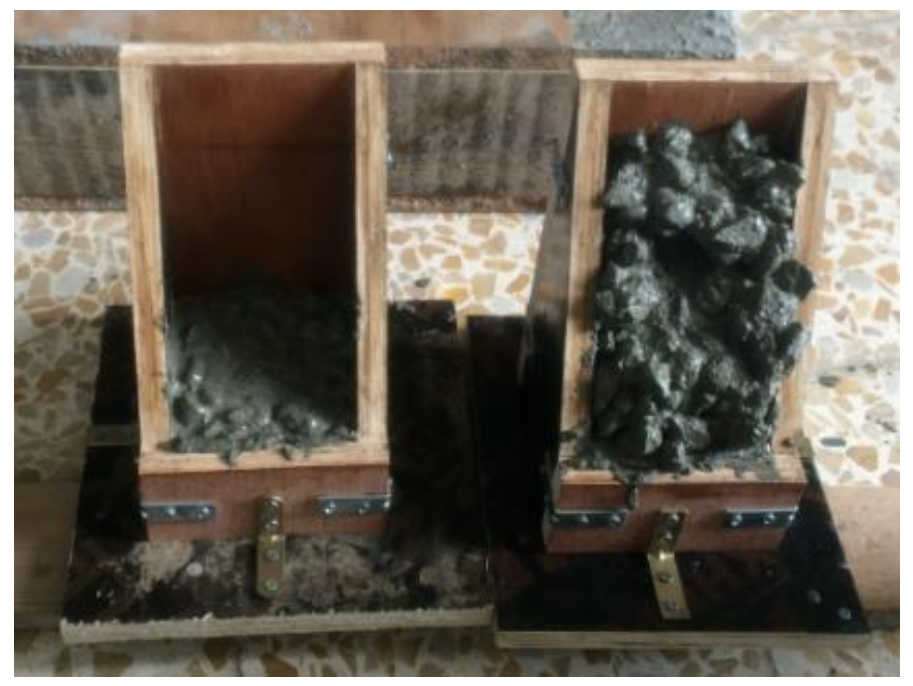

Fig. 4: Casting of ordinary concrete (substrate part)

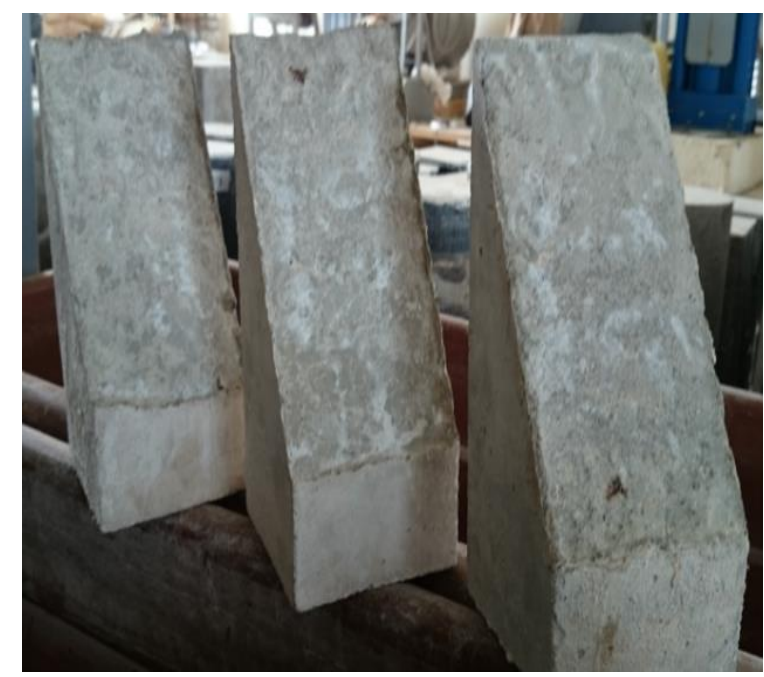

Fig (5) : Hardened ordinary concrete sample

Roughness of the interfacial surface between OC and HSC has been improved to provide suitable bond between these parts. Three modes of treatment are selected to prepare roughed interface, namely, holes with depth of $1 \mathrm{~cm}$, grooves with depth of $1 \mathrm{~cm}$ and sand blast as depicted in Fig. 6. The upper new part of HSC for hybrid concrete samples is cast using three mixes of HSC given in Table 3. HSC mix is prepared by mixing dry materials for 3 min followed by adding $60 \%$ of the required water with mixing for another $3 \mathrm{~min}$. The remained $40 \%$ of the water has been added to the superplasticizer and mixed. The mixture is introduced to the concrete batch and the mixing has been performed for 10-15 min. Fresh HSC is cast on the old normal concrete substrate with treated surface as fast as possible to prevent the rapid setting of the fresh HSC.
New HSC concrete is poured in one layer over old concrete with taping on the mold sides to prevent air voids in the mix and finally the upper surface has been leveled with the mold edge (Fig. 7). Twenty samples (Table 7) of hybrid concrete prism have been used to measure their compressive and slant shear strengths.

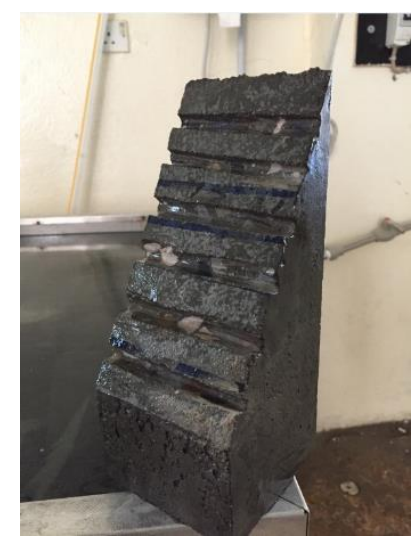

a- Grooves

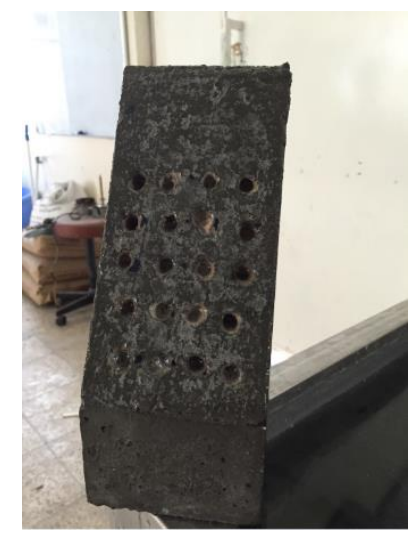

b- Holes

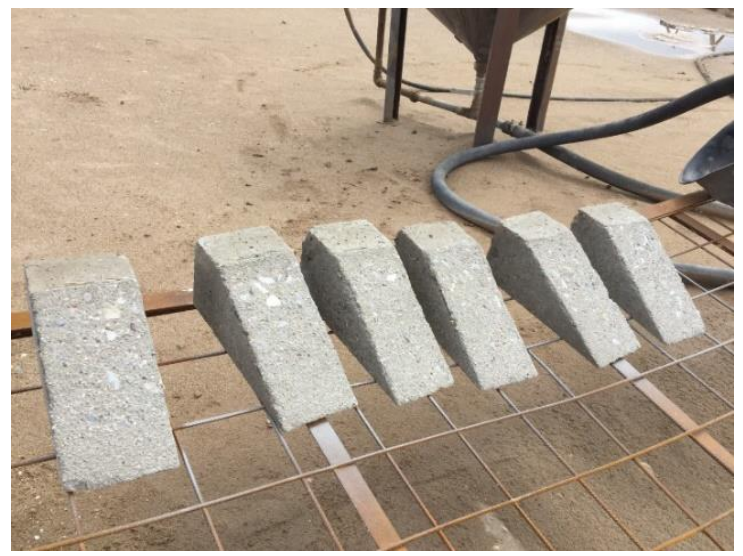

c- Sand blast

Fig (6) : Surface treatment of the ordinary concrete substrates 


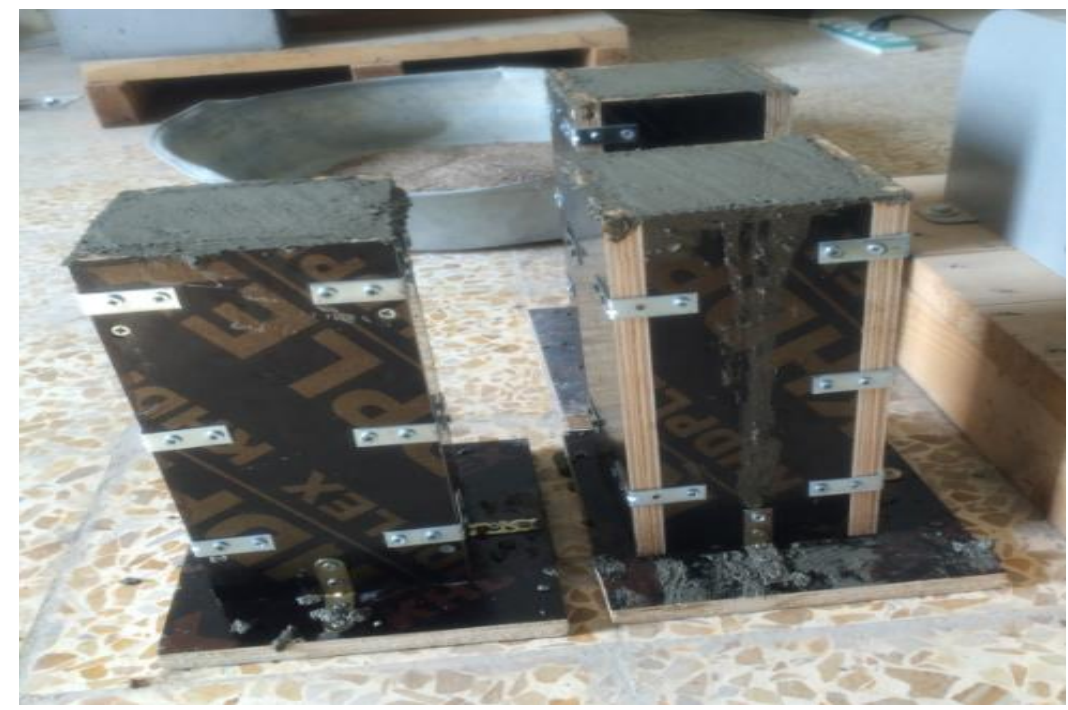

Fig (7) : Hybrid concrete samples after casting of HSC part

Table (7) : Concrete samples used in measuring of slant shear strength

\begin{tabular}{|c|c|c|c|}
\hline No. & $\begin{array}{c}\text { Sample } \\
\text { designation }\end{array}$ & Type of concrete & $\begin{array}{c}\text { Number } \\
\text { of } \\
\text { prepared } \\
\text { samples }\end{array}$ \\
\hline 1 & Control & Ordinary Concrete (OC) & 2 \\
\hline 2 & SFH & Hybrid concrete (silica fume and holes) & 2 \\
\hline 3 & SFGr & Hybrid concrete (silica fume and grooves) & 2 \\
\hline 4 & SFSB & Hybrid concrete (silica fume and sand blast) & 2 \\
\hline 5 & GRH & Hybrid concrete (waste glass powder and holes) & 2 \\
\hline 6 & GPGr & Hybrid concrete (waste glass powder and grooves) & 2 \\
\hline 7 & GPSB & Hybrid concrete (waste glass powder and sand blast) & 2 \\
\hline 8 & (SF+GP)H & $\begin{array}{c}\text { Hybrid concrete (mixed silica fume and waste glass } \\
\text { powder with holes) }\end{array}$ & 2 \\
\hline 9 & (SF+GP)Gr & $\begin{array}{c}\text { Hybrid concrete (mixed silica fume and waste glass } \\
\text { powder with grooves) }\end{array}$ & 2 \\
\hline 10 & (SF+GP)SB & $\begin{array}{c}\text { Hybrid concrete (mixed silica fume and waste glass } \\
\text { powder with sand blast) }\end{array}$ & 2 \\
\hline \multicolumn{2}{|c|}{ Total samples } \\
\hline
\end{tabular}

\section{Results and Discussion.}

\subsection{Compressive strength of the concrete cubes}

The average compressive strength (Table 8) has been recorded for three cubes made with each concrete mix at 28 day age. Highest strength can be observed with using silica fume in HSC in comparison to waste glass powder due to the conventional pozzolanic reactivity of silica fume.

Table (8) : Compressive strength of concrete cubes

\begin{tabular}{|c|r|c|}
\hline No. & Concrete type & $\begin{array}{c}\text { Compressive Strength MPa at } \\
\text { 28-day age }\end{array}$ \\
\hline 1 & Normal concrete & 30.4 \\
\hline 2 & HSC with silica fume & 158 \\
\hline 3 & HSC with waste glass powder & 98 \\
\hline 4 & HSC with silica fume and glass powder & 137 \\
\hline
\end{tabular}




\subsection{Strength of the hybrid concrete}

The behavior of hybrid concrete prisms under compressive load has been examined in terms of their slant shear strength. This property is calculated as listed in Table 9 using the following expression:

Table (9) : Slant shear strength of hybrid concrete prisms

\begin{tabular}{|c|c|c|}
\hline No. & Sample designation & Slant shear strength (MPa) \\
\hline 1 & Control & 17.88 \\
\hline 2 & SFH & 6.26 \\
\hline 3 & SFGr & 16.53 \\
\hline 4 & SFSB & 9.64 \\
\hline 5 & GRH & 6.26 \\
\hline 6 & GPGr & 15.00 \\
\hline 7 & GPSB & 14.24 \\
\hline 8 & (SF+GP)H & 10.17 \\
\hline 9 & (SF+GP)Gr & 15.93 \\
\hline 10 & (SF+GP)SB & 10.85 \\
\hline
\end{tabular}

The average slant shear strengths of the hybrid concrete prisms with interfacial surface treated with holes, sand blast and grooves are $7.57 \mathrm{MPa}, 11.58 \mathrm{MPa}$ and $15.82 \mathrm{MPa}$, respectively. In the other words, slight reduction of $11 \%$ in the strength can be observed with using grooved interface in comparison to control prism strength. Accordingly, a remarkable improvement in the hybrid concrete strength can be achieved with using grooved interfacial surface between old and new concretes. The average slant shear strength has been measured with respect to the used powders, namely, silica fume, waste glass powder and their mixture as 10.82 $\mathrm{MPa}, 11.84 \mathrm{MPa}$ and $12.32 \mathrm{MPa}$, respectively. It is observed that the strengths of the retrofitted concretes made with silica fume and waste glass powder are
Slant shear = Maximum applied compressive force / slant area of the specimen ... (1)

where, slant area of the specimen $=115.47 \mathrm{~cm} 2$ relatively similar and equivalent to $64 \%$ of control sample strength. However, the mixture of both powders is regarded a best choice in the present study.

\subsection{Failure modes of the hybrid concrete samples}

The failure mode of the hybrid concrete specimens is varied such as columnar, interfacial and combined failures (Fig. 8). Failure mode for each specimen is given in Table 10. It is obvious that the failure pattern for the hybrid concrete with grooved interfacial surface gives similar failure to that of control ordinary concrete specimen. Moreover, the type of the utilized powder in HSC has no remarkable effect on the failure mode of hybrid concrete with grooved interface.

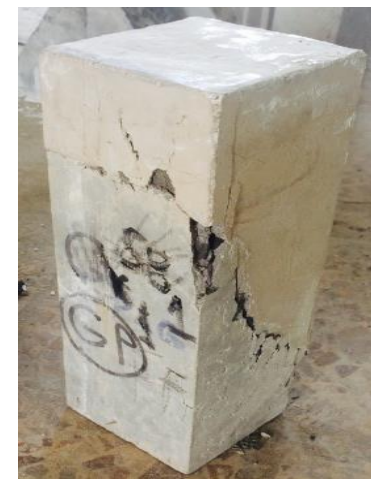

Columnar failure

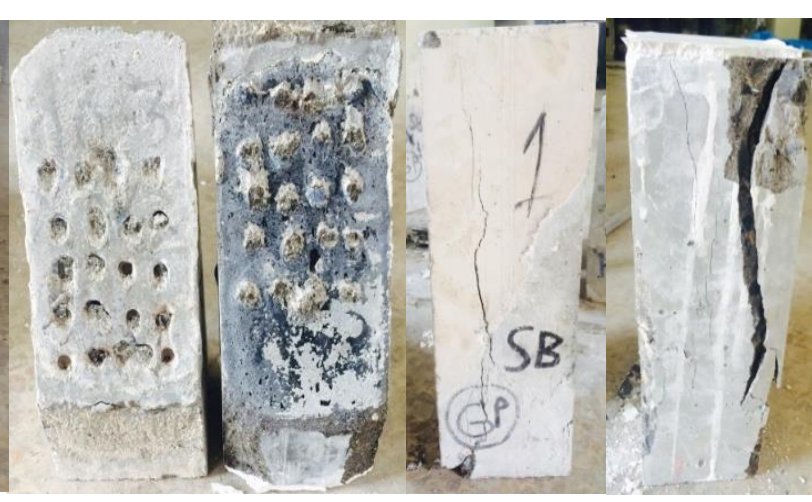

Interfacial failure
Combined failure
Fig (8) : Failure modes of concrete specimens 
Table (10) : Failure mode of each hybrid concrete sample

\begin{tabular}{|c|c|c|}
\hline No. & Prism designation & Mode of failure \\
\hline 1 & Control & Columnar \\
\hline 2 & SFH & Columnar \\
\hline 3 & SFGr & Interface \\
\hline 4 & SFSB & Interface \\
\hline 5 & GPH & Columnar \\
\hline 6 & GPGr & Columnar \\
\hline 7 & GPSB & Interface \\
\hline 8 & $($ SF+GP)H & Columnar \\
\hline 9 & $($ SF+GP)Gr & Columnar + Interface (combined) failure \\
\hline 10 & (SF+GP)SB & \\
\hline
\end{tabular}

\section{CONCLUSIONS}

According to the measurements of current experimental work, several conclusions can be drawn as hereunder: -

1- Waste glass powder can be used with the equivalent efficiency to silica fume in enhancing slant shear strength for hybrid concrete made with old and new parts.

2- Reasonable bond between old ordinary concrete and new HSC can be achieved via grooved interfacial surface between these concrete parts in hybrid concrete element.

3- Failure mode at collapse of the hybrid concrete with grooved interfacial surface was not affected by the pozzolanic reactivity of the used powders in HSC.

\section{REFERENCES}

Ali YAZ, Ambalavanan R (1999) Flexural behaviour of reinforced concrete beams repaired with styrenebutadiene rubber latex, silica fume and methylcellulose repair formulations. Mag Concrete Res 51, 113-120.

American Society of Testing Materials (ASTM) (2007) Manual of aggregate and concrete testing, Vol. 0402.

Ankur M, Randheer S (2012) Comparative study of waste glass powder as pozzolanic material in concrete. National Institute of Technology Rourkela.

Azad A, Hakeem I (2013) Flexure behavior of hybrid high performance concrete construction. Research, Development, and Practice in Structural
Engineering and Construction.

Brandt AM (2008) Fibre reinforced cement-based (FRC) composites after over 40 years of development in building and civil engineering. Composite Structures 86, 3-9.

Denarié E, Brühwiler E (2006) Structural rehabilitations with ultra high performance fibre reinforced concretes. International Journal for Restoration of Buildings and Monuments, Aedificatio, 453-467.

Garbacz A, Gorka M, Courard L (2005) Effect of concrete surface treatment onadhesion in repair systems. Mag

Graybeal BA (2006) Material Property Characterization of Ultra-High Performance Concrete, Report No. FHWA-HRT-06-103, Federal Highway Administration, Washington, DC.

Graybeal BA (2009) UHPC making strides, Public Roads, Federal Highway Administration, McLean, VA, 72, 17-21.

Habel K, Viviani M, Denarié E, Brühwiler E (2006) Development of the mechanical properties of an Ultra-High Performance Fiber Reinforced Concrete (UHPFRC). Cement and Concrete Res 36(7), 13621370.

Harris DK, Sarkar J, Ahlborn TM (2011) Interface bond characterization of ultra-high performance concrete overlays. In: Transportation Research Board: 90th Annual Meeting.

Julio ENBS, Branco FAB, Silva VD (2004) Concrete-toconcrete bond strength.Influence of the roughness 
of the substrate surface. Constr Build Mater 18(9), 675-681.

Li VC (2003) On engineered cementitious composites (ECC). Journal of Advanced Concrete Technology, 1, No. 3, 215-230.

Li VC, Wang S, Wu C (2001) Tensile strain-hardening behavior of polyvinyl alcohol engineered cementitious composite (PVA-ECC). ACI Mater J $98,483-492$.

Markovic I (2006) High-performance hybrid-fibre concrete: development and utilisation, $\mathrm{PhD}$ thesis, Delft University of Technology.

Momayez A, Ehsani MR, Ramezanianpour AA, Rajaie $\mathrm{H}$ (2005) Comparison of methods for evaluating bond strength between concrete substrate and repair materials. Cement Concrete Res 35(4), 748757.

Mu B, Meyer C, Shimanovich S (2002) Improving the interface bond between fiber mesh and cementitious matrix. Cement Concrete Res 32(5), 783-787.

Naaman AE, Homrich JR (1989) Tensile stress-strain properties of SIFCON. ACI Mater J 86, 244-251.

Naaman AE, Reinhardt HW (2006) Proposed classification of HPFRC composites based on their tensile response. Mater Struct 39, 547-555.

Pfeifer CG, Moeser B, Giebson C, Stark J (2009) Durability of ultra-high-performance concrete, Tenth ACI International Conference on Recent Advances in Concrete Technology and Sustainability Issues, No. SP-261-1.

Tayeh BA., Abu Bakar BH, Megat Johari MA, Voo YL
(2012) Mechanical and permeability properties of the interface between normal concrete substrate and ultra-high performance fiber concrete overlay. Constr Build Mater 36, 538-548.

Rossi P (1997) High performance multimodal fiber reinforced cement composites (HPMFRCC): the LCPC Experience. ACI Mater J 94: 478-483.

Santos PMD, Julio ENB (2011) Factors affecting bond between new and old concrete. ACI Mater J 108(4), 449-456.

Sarsam KF, Mohammed MH (2014) Load-Deflection Behavior of Hybrid Beams Containing Reactive Powder Concrete and Conventional Concrete. Journal of Engineering and Development 18(3), 118147.

Smarzewski P., Barnat-Hunek D (2017) Property assessment of hybrid fiber-reinforced ultra-high performance concrete. J Civ Eng. doi:10.1007/s40999-017-0145-3

Vaysburd A, Emmons P (2000) How to make today's repairs durable for tomorrow-corrosion protection in concrete repair. Constr Build Mater 14(4), 189197.

Wille K, Naaman AE, Parra-Montesinos GJ (2011) Ultrahigh performance concrete with compressive strength exceeding $150 \mathrm{MPa}$ (22 ksi): A simpler way. ACI Mater J 108, 46-54.

Yuan YS, Marosszeky M (1991) Major factor influence the performance of structural repair. Evaluation and rehabilitation of concrete structures and innovations in design. Proceedings of ACI international conference, Hong Kong, p. 128-150. 